\title{
福井県若狭地方の“サバなれずし”の特徵
}

漬け床およびすしの化学組成の変化と揮発成分の生成

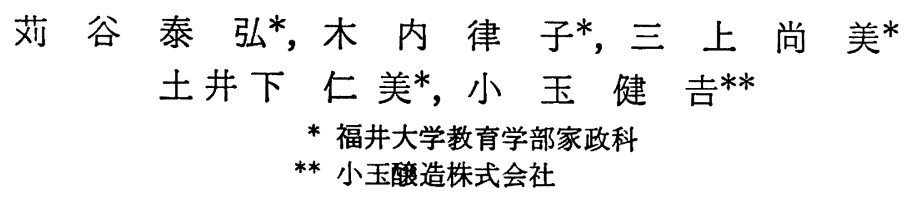

\section{Characteristics of Saba-narezushi (Mackerel and Pickles) Produced in the Wakasa Region of Fukui Prefecture}

Chemical Changes in the Fermentation Medium and Mackerel Meat during

Fermentation and the Production of Volatile Components

Yasuhiro KARIYA,* Ritsuko KIUCHI,* Naomi MIKAMI,*

Hitomi DOISHITA* and Kenkichi KODAMA**

* Department of Home Economics, Faculty of Education, Fukui University, Fukui 910

** Kodama Brewing Co. Ltd., Iitagawa, Akita 018-15

\begin{abstract}
Nippon Eiyō Shokuryō Gakkishi (J. Jpn. Soc. Nutr. Food Sci.) 43, 43 48 (1990)
Saba-narezushi (mackerel and pickles), a fermented fish product from the Wakasa bay area of Fukui Prefecture, was prepared in the laboratory using desalted heshiko (salted mackerel cured with rice bran), koji (rice malt), and boiled rice according to the traditional process, and analyzed for its contents of reducing sugar, organic acids, amino acids, alcohols and esters. After fermentation, reducing sugar accounted for about $4.2 \%$ by weight of the fermentation medium, and organic acids for about $1 \%$, and amino acids about $0.95 \%$. Lactic acid and citric acid were found as the major acids and acetic acid as a minor volatile acid. Major volatile compounds found by gas chromatography in the fermentation medium were ethanol and ethyl acetate.
\end{abstract}

Key Words heshiko, ethyl acetate, acid protease, neutral protease, acetic acid.

(Received July 7, 1989)

福井県小浜市に属す若狭湾沿岸の漁村に伝わる“サバ のなれずし”は，古くから作られてきた正月用の“晴れ の食べ物”の一つである。この“なれずし”は，海岸部 から遠く離れた農山村に運ばれて普及して，重宝される ばかりでなく，漁民にとっても冬期海荒れの時期におけ る収入源であるとともに, 貴重な動物性タンパク供給源 でもあった。

“なれずし”は，本来魚に恵まれない地域での魚の貯 蔵法から生まれたもので1)，塩漬けした魚を脱塩して，

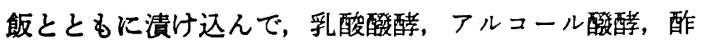
酸嘸醉あるいは酪酸酸醉などの混合酸酵による漬け込み

* 干910 福井市文京 3-9-1

** $=018$ 秋田県南秋田郡飯田川町
床の酸性化によって熟成させたものである。

“なれずし”は，製造される地域によって，魚の種類 が異なり，副原料として野菜類や米コウジなども用いら れる。たとえば，秋田県から北海道にかけての“八タハ タの飯鮨（イズシ)”や“サンマの飯鮨”にはコウジが用 いられるし, 滋賀県琵琶湖沿岸地域で作られる鮊鮨は, “鮒”を使った“なれずし”の代表的なものである1。

サバを原料とする“なれずし”は, 本報のもの以外に 京都府北部の美山町のものや, 富山県城端町や井波町の ものがあり, 和歌山県伊都, 海草, 有田, 日高の各郡や 熊野地方の“生成れ”る有名である。

これらの“なれずし”のなかには, 産地による製法上 の特徵があって, その特徵が製品の香味に微妙に作用し 


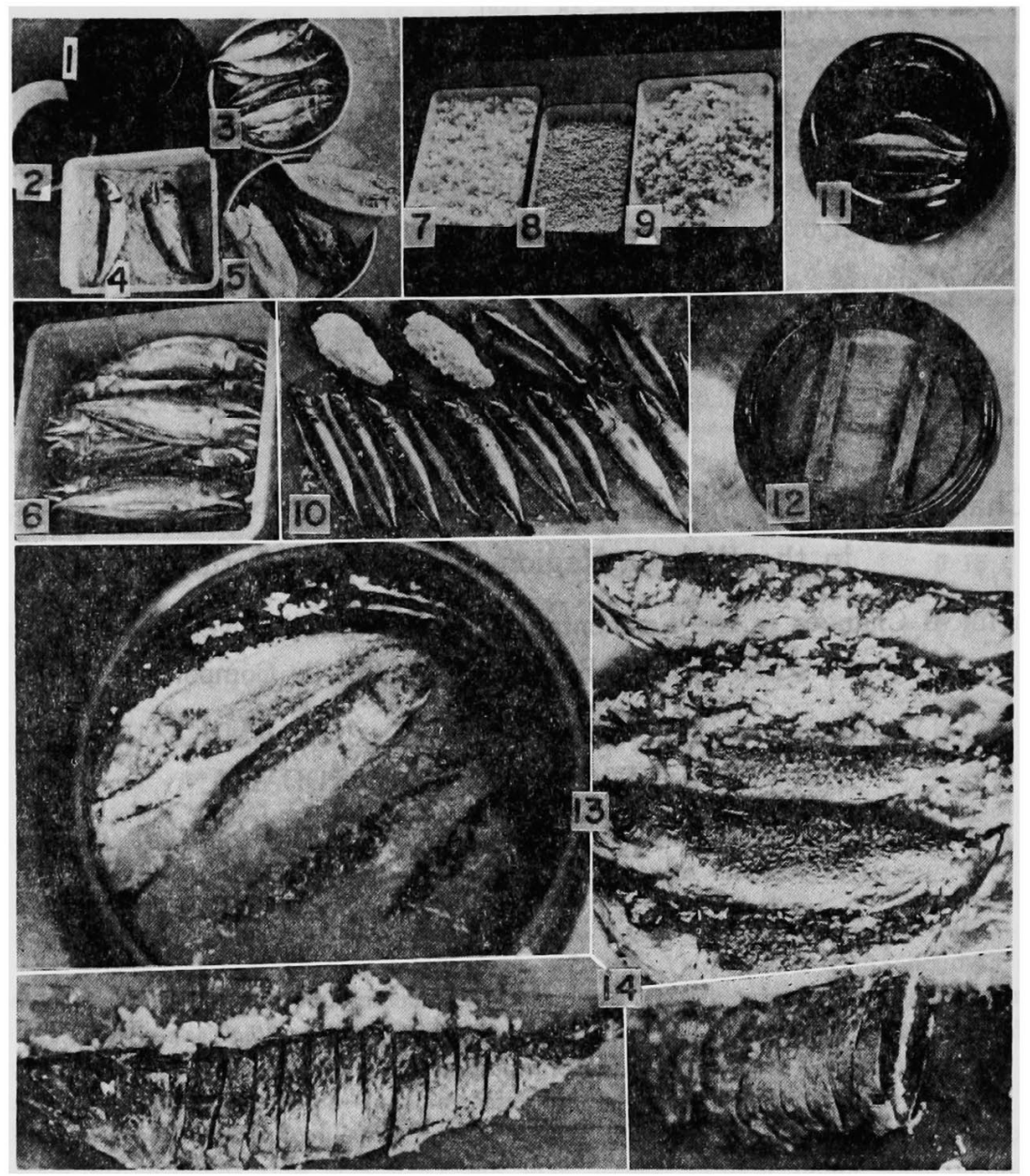

Photo. 1. Materials for mackerel and pickles production.

1, Vessel for fermentation; 2, Saline extract of mackerel; 3, Salted fish ; 4, Rice bran; 5 , Salted fish covered with rice bran (2 to 5 are materials for making Heshiko); 6, Heshiko desalting ; 7, Boiled rice ; 8, Koji ; 9, Mixture of boiled rice and Koji; 10, Desalted fish packed with materials for fermentation; 11, Packing in the fermentation vessel; 12 , Surface of the vessel covered with leaves of low striped bamboo; 13, Mackerel and pickles in and out of the fermentation medium; 14, Edible mackerel and pickles.

て異臭とさえ感じられるものを放つものがある。この臭 気は、食べ馿れない者にとっては,およそ食欲の対象と はならない特異的なものでもある。

本報では，若狭の“サバなれずし”の製造時における 魚肉および漬け床の化学組成の变化と, 香気成分の生成 とその組成について検討した結果を報告する。

\section{材料および実験方法}

\section{1.“なれずし”漬け込み材料}

主原料のサバは, 産卵期直前の春サハ（4 月下旬から 5 月上旬に獲られたもの）を背開きにして，内蔵とェラ を除き，10日間はど十分な重石をして塩漬けする。魚と
塩魚汁を分けて，魚には米糠と塩をまぶして別の容器に 詰め，魚と魚の間陌には適当に塩と米棣を詰めて平らに し，塩魚汁を戻して押し蓋の上に重石をして数カ月間漬 けて“へしこ”を調製する2”。この“へしこ”を流水中 で脱塩して，水切り後 “なれずし”の原料として使用し た。“なれずし”の漬け込み材料およびできあがり製品 をPhoto. 1 に示し, 漬け込み配合の例を Table 1 に示 した。

\section{2. 分析方法}

“なれずし”製造期間中の魚肉拈よび漬け床中の含窒 素化合物量, 還元糖, 有機酸等の測定方法は, 前報233に 準じた。遊離型アミノ酸 (free form) とは, 試料溶液 1 
Table 1. Materials for mackerel and pickles production.

\begin{tabular}{ll}
\hline \hline Heshiko (desalted) & 57 heads \\
Boiled rice & $5.55 \mathrm{~kg}$ (as polished rice) \\
Koji* & $3.0 \mathrm{~kg}$ (as polished rice) \\
$1 / 2$ diluted Sho-chu & $500 \mathrm{ml}$ \\
\hline
\end{tabular}

* Amylase activity, 0.15 unit/g; neutral protease activity 17.09 units/g.

部に対し, $0.3 \mathrm{~N} \mathrm{Ba}(\mathrm{OH})_{2}, 0.5$ 部と, $5 \% \mathrm{ZnSO}_{4}, 0.5$ 部を加えてよく擋找し，生した沈殿を東洋ろ紙 No. $5 \mathrm{C}$ で自然ろ過して得られたろ液中に存在するアミノ酸であ る。ペプチド型アミノ酸 (peptide form) は, 試料溶液 に等量の $4 \mathrm{~N} \mathrm{HCl}$ を加えて沸騰湯浴中で 2 時間加水分 解したのち， $2 \mathrm{~N} \mathrm{NaOH}$ で中和したものを，前述の 0.3 $\mathrm{N} \mathrm{Ba}\left(\mathrm{OH}_{2}\right)$ と $5 \% \quad \mathrm{ZnSO}_{4}$ で除タンパクしたろ液中に 存在する全アミノ酸量から遊離型アミノ酸量を差し引き したものである。タンパク型アミノ酸 (protein form) は次のよ5にして求めた。試料を $6 \mathrm{~N} \mathrm{HCl}$ 濃度で沸腾 湯浴中で 24 時間加水分解後, 湯浴上で蒸発乾固させた のち, 固型 $\mathrm{KOH}$ を乾燥㓮として減圧デシケーター中で 減圧して乾燥と同時に塩化水素を除いた。この標品を一 定量の蒸留水に溶解してろ過して, アミノ酸を定量し, 定量値から遊離型とペプチド型アミノ酸量を差し引きし た残りをタンパク型フミノ酸量とした。

コウジ4) のアミラーゼ活性は，コウジ $100 \mathrm{~g}$ に M/5 $\mathrm{Na}$-リン酸緩衝液 $(\mathrm{pH} 6.0), 150 \mathrm{ml}$ を加え, 氷冷下で 3 分間ホモジナイズしたものを, $0^{\circ} \mathrm{C}, 15,000 \mathrm{rpm}, 20$ 分 間遠心分離して得られた上清液 $10 \mathrm{ml}$ を粗醉素液とし, 等量の $10 \%$ 可溶性デンプン溶液を基質として加えて, $30^{\circ} \mathrm{C}$ で $30,60,90$ および 120 分間反応させて，生成す る還元煻をべルトラン法で定量し， 1 時間当り $1 \mathrm{mmol}$ のグルコースを生成する活性を 1 単位とした。中性プロ テフーゼ活性は $\mathrm{M} / 5 \mathrm{Na}$-リン酸緩衝液（ $\mathrm{pH} 6.0 ）$ に $0.6 \%$ 濃度に溶解したカゼイン $4 \mathrm{ml}$ を試験管に採り 1 $\mathrm{ml}$ の上記粗酵素液を加えて $30^{\circ} \mathrm{C}$ で反応させ，遊離す るチロシンを Anson の萩原変法5) で測定し， 1 時間に $1 \mu \mathrm{g}$ のチロシン当量を遊離する活性を 1 単位として示 した。漬け床液の中性プロテフーゼ活性は上記と同様に して測定した。酸性プロテアーセ活性は，1 $\mathrm{M}$ 酶酸緩衝

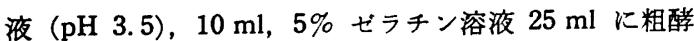
素液 $15 \mathrm{ml}$ 拉よびトルオール $0.5 \mathrm{ml}$ を加えた反応液を $40^{\circ} \mathrm{C} て ゙ 3$ 時間反応させて, 生成するアミ，態窒素をホル モール滴定法で定量して，1時間当り $1 \mathrm{mg}$ のアミノ態 窒素を遊離する活性を 1 単位とした。

香気成分は，“なれずし”の漬け床約 $500 \mathrm{~g}$ を，2lの 枝付丸底フラスコに採り, 水蒸気蒸留して得られる初留

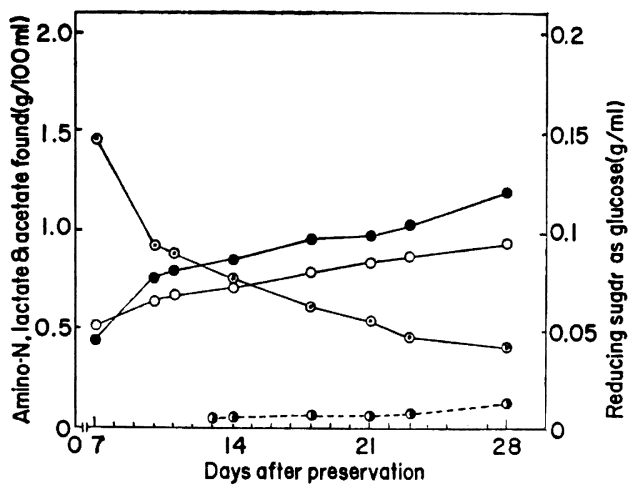

Fig. 1. Chemical changes in fermentation medium. $\odot$, reducing sugar; $\bullet$, nitrogen as amino acid;

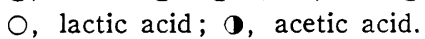

画分約 $30 \mathrm{ml}$ を氷冷下で採取して，ガスクロマトグラ フィーで分析した。

\section{結果および考察}

\section{1. “サバなれずし”の渍け床液の化学組成と香気の} 変化

Table 1 に示した材料で漬け込み, 容器を室内の冷所 に静置すれば，4〜5 日後に仕込み材料の上面に透明な 液体が渗出した。この液量は時日の経過とともに增加 し，12 13 日後には液の表面に産膜酵母 (Hansenula anomala 扣よびその近縁種 $)^{6)}$ が, 乾燥性白色の皮膜を 形成して增殖した。この酵母の皮膜は, 漬け込み 3 週間 後には約 $0.5 \mathrm{~cm}$ の厚さを示した。漬け床は, 漬け込み 当初，米コウジ臭を放つか，しだいに芳香を発するよう になり，産膜酵母の皮膜を形成する時期には清酒モ口ミ 様の芳香となった。さらに日数を経過すると，芳香は酢 酸エチル臭となった。

上清液中の還元糖量, アミノ態窒素量, および酸度の 経時的変化を Fig.1 1示した。

還元糖量は, 試料採取が可能となった漬け込み 7 日後 には $145 \mathrm{mg} / \mathrm{ml}$. 存在した。その後は時間の経過ととも に減少して，10 日後には $92 \mathrm{mg} / \mathrm{ml}, 14$ 日後には 75 $\mathrm{mg} / \mathrm{ml}, 22$ 日後には $55 \mathrm{mg} / \mathrm{ml}$ となり，28 日後には $42 \mathrm{mg} / \mathrm{ml}$ となった。漬け床液中の還元煻量は, 使用し たコウジの量に応じて変化するものであって、コウジの 量が多ければ当初の還元糖量は多く, 熟成の終了する時 期にもなおかなりの量が存在して、“なれずし”に甘味 を与えるものである223)。還元糖量の減少は，漬け床に 增殖する微生物による醱酵の結果であって, 有機酸や香 気成分となるアルコール類の生成は，これらの微生物に よって行われる。

全酸度は，漬け込み 7 日後には乳酸として䄪 $0.5 \%$ で 
Table 2. Changes in amino acid compounds in the fermentation medium.

\begin{tabular}{cccc}
\hline \hline \multirow{2}{*}{$\begin{array}{c}\text { Days after } \\
\text { fermentation }\end{array}$} & \multicolumn{3}{c}{ Amino acid found $(\mathrm{mg} / 100 \mathrm{ml})$} \\
\cline { 2 - 4 } & Peptide-form $(A)$ & Free-form $(B)$ & $(A)+(B)$ \\
\hline 12 & 210.42 & 878.04 & $1,088.46$ \\
18 & 470.16 & 880.92 & $1,351.08$ \\
23 & 439.56 & 996.12 & $1,435.68$ \\
28 & 282.24 & $1,212.30$ & $1,494.54$ \\
\hline
\end{tabular}

Table 3. Chemical changes in mackerel meat during fermentation.

\begin{tabular}{|c|c|c|c|c|c|}
\hline & \multirow{2}{*}{$\begin{array}{c}\text { Water content } \\
(\%)\end{array}$} & total $\mathrm{N}$ & amino-N & ammonia-N & amide- $\mathrm{N}$ \\
\hline & & \multicolumn{4}{|c|}{ (mg per $100 \mathrm{~g}$ dried sample) } \\
\hline Raw fish & 65.30 & 6,962 & 105.50 & 5.50 & 4.00 \\
\hline Heshiko & 44.00 & 6,622 & 143.40 & 18.90 & 7.20 \\
\hline \multicolumn{6}{|c|}{$\begin{array}{l}\text { Days after } \\
\text { fermentation }\end{array}$} \\
\hline 0 day & 56.20 & 6,383 & 36.70 & 3.70 & 5.30 \\
\hline 14 days & 54.70 & 7,132 & 215.40 & 7.60 & 8.40 \\
\hline 28 days & 53.20 & 6,832 & 238.00 & 15.70 & 62.90 \\
\hline
\end{tabular}

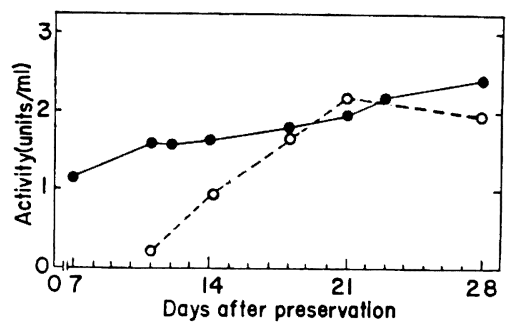

Fig. 2. Changes in proteolytic activity of the fermentation medium.

$\bigcirc$, acid protease; $\bullet$, neutral protease.

The reaction was carried out at $30^{\circ} \mathrm{C}$.

あったが，14 日後では $0.75 \% ， 28$ 日後には $0.95 \%$ とな った。全酸度の約 $10 \%$ は揮発性酸であって, 酢酸と同 定した ${ }^{3)}$ 。不揮発性酸の大部分は,クェン酸と乳酸であ っだ)。

漬け床液中のアミノ酸窒素量は, 漬け込み 7 日後 0.45 \%であったが, 10 日後には $0.75 \%, 14$ 日後には $0.85 \%$ ， 21 日後に約 $1 \%$ となり，28 日後には $1.1 \%$ となった。 このように漬け床液には, 還元糖, 揮発性酸, 不揮発性 酸およびアミノ酸窒素の増加といら一般の漬け物類の製 造に必要な調味成分の蓄積が認められた。

漬け床液中のアミノ態窒素量を遊離型とペプチド型に 分別すると, Table 2 に示すように, 遊離型は漬け込み
の期間を通して増加しているが，ペプチド型は一時的に 増加したのち減少するパターンを示した。このぺプチド 型アミノ態窒素量の量的変化は, 漬け床材料および漬け 込み物質のタンパク質分解の着実な進行を示㖫するもの である。漬け床液のタンパク質分解活性を代表する酸性 および中性プロテアーゼ活性は, Fig. 2 に示すように, 時間の経過とともに増加している。この増加は, 漬け床 液中に增殖する微生物由来の活性が, コウジ由来の活性 に加味された結果と考えられる。

\section{2. “なれずし”の含窒素化合物量の変化}

原料扣よび加工の段階で, サパの含窒素化合物量の変 化を比較すると, Table 3 に示すように, アミノ態窒素 量は鮮魚から“へしこ”への加工時に増加している。し かしながら、このアミノ態窒素は，“なれずし”の潰け 込みに先立って行われる脱塩操作でほとんと流失してい ることがわかる。したがって，“なれずし”の熟成は魚 肉タンパク質の可溶化, ペプチド化扣よび遊離型アミ， 酸への加水分解反応によってもたらされると考えられ る。したがって, 熟成の進行過程では, 魚肉から漬け床 へとアミノ酸が遊離していく可能性を考虑しなければな らない。しかしながら，魚肉中の遊離型アミノ酸量と漬 け床液中に蓄積された遊離型アミノ酸量を Table 3 と Fig.1 の結果から比較すると, 漬け床液中のアミノ酸量 は魚肉中に認められる量の $3 \sim 4$ 倍多い。この結果か 


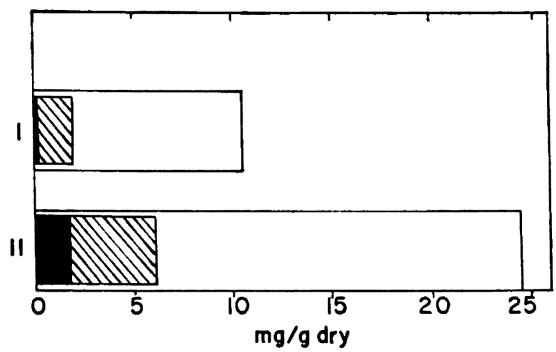

Fig.3. Forms of amino-N found in the watersoluble fraction of mackerel and pickles before and after fermentation.

$\square$, free form; $\square$, peptide form; $\square$, total. I, before fermentation; II, after fermentation.

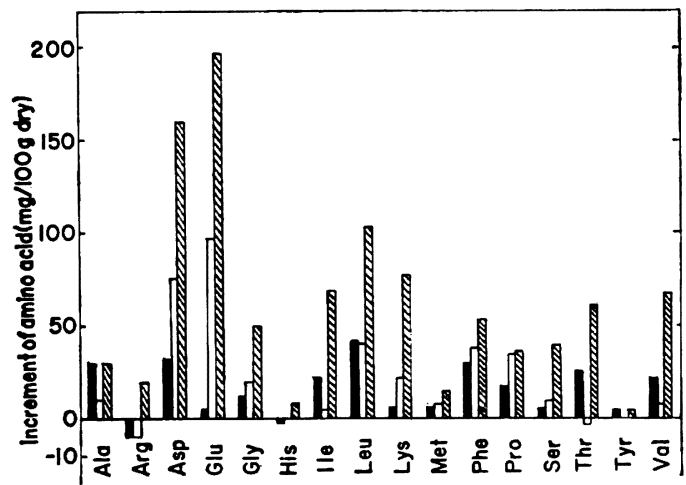

Fig.4. Changes in amino acid compositions in the water-soluble fraction of mackerel and pickles by fermentation for 28 days.

$\square$, free form; $\square$, peptide form; $\square$, protein form.

ら，“なれずし”の熟成の進行中には, 魚肉から漬け床 へのアミノ酸の渗出よりは, むしろ漬け床液中に生成し たアミノ酸やその他の糖や有機酸などが魚肉中に侵入す る可能性が高いと考えられる。

28 日間の漬け込みを行った“なれずし”の水溶珄画分 中のアミノ酸を, 遊離型およびペプチド型アミノ酸と全 構成アミノ酸に分別して Fig.3に示した。

漬け込みによって, 水溶性画分中の全構成アミノ酸量 は約 2 倍に増加しており, ペプチト゚型アミノ酸も 2.2 倍 に増加した。同様に, 遊離型アミノ酸は,ほほ 11 倍に 増加した。

それぞれの画分を構成するアミノ酸を分別定量して, 漬け込みの前後での各アミノ酸の増減量を比較した。

Fig.4 に示すように，漬け込みによって減少した遊離 型アミノ酸は, アルギニン(Arg) とヒスチジン (His) である。ペプチド型アミノ酸では, Arg とスレオニン (Thr) が減少したが, その他のアミノ酸は漬け込みによ

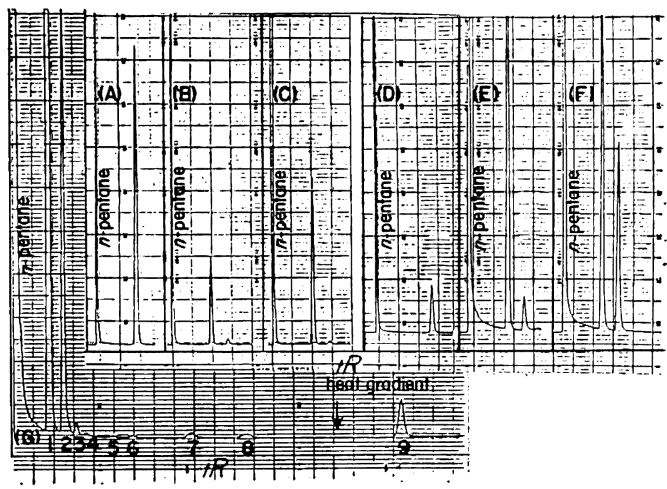

Fig.5. Gas-chromatogram of aroma components in fermentation medium of mackerel and pickles.

(A), authentic ethyl acetate; (B), sample; (C), sample+ethyl acetate; (D), authentic ethanol; (E), sample ; (F), sample + ethanol; (G), sample. Peak No. 1 corresponds to ethyl acetate; peak No. 2 corresponds to ethanol; peaks No. 3 to 9 are not identified yet. Column; PEG $20 \mathrm{M}, 20 \%$; column temp. $50^{\circ} \mathrm{C}$; injection temp. $130^{\circ} \mathrm{C} ; \mathrm{N}_{2}$ gas flow rate, $50 \mathrm{ml} / \mathrm{min}$; FID detector; Chart speed $5 \mathrm{~mm} / \mathrm{min}$.

ってすべて増加した。遊離型では, アラニン(Ala), ア スパラギン (Asp), ロイシン (Leu), フェニルアラニン (Phe), Thr, バリン (Val) などが顕著な増加を示し, ペプチド型では, Asp, グルタミン(Glu), Leu, Phe, プロリン(Pro) などが増加した。漬け込みによって, 遊 離型でもぺプチド型でもない高分子量の水溶性タンパク 画分が増加しており，この画分を菁成するてミノ酸は, Glu, イソロイシン (Ile), Leu, リジン (Lys), Phe,

Thr, Val などが量的に多いことがわかった。

以上の結果から，“サバなれずし”の熟成は，魚肉タ ンパク質が完全に遊離型アミノ酸に分解されるのみでは なくて, 魚肉タンパク質の水溶性化をも伴うものといえ る。

\section{3. 香気成分}

漬け床の揮発性成分のうち，酸性物質は酢酸として同 定したが3)，漬け床をそのまま水蒸気蒸留して得られた 留出画分のガスクロマトグラフィーの結果から, Fig. 5 に示すように香気の主成分としてェチルフルコールと酢 酸エチルを同定した。留出液中にはその他に極く微量の 未同定の高級アルニール，あるいはそのェステル様物質 が含まれていた。

富山県城端町善徳寺の“サバなれずし”の漬け床から は酪酸エチルや低級フミン類を検出したが6)，若狭のも のからはそれらは検出されなかった。

善徳寺の“なれずし”と若狭の“なれずし”の香気の 
違いは，原料と漬け込み時期の違いによるものと考えら れる。すなわち，前者では塩漬けサバを用いるのに対 し，後者では “へしこ”を用いており，前者では 5 月下 旬から 7 月下旬の高温の時期に漬け込むのに対して, 後 者では晚秋から初冬の低温の時期に漬け込む。

塩漬けのみのサバを使った“なれずし”は，“鮒鮨”や “生成れ”のような独特の魚臭を有しているが，“へし こ”を使うと魚臭は感じられない。

漬け込 みの時期が高温の時期では，安定した乳酸醴酵 やアルコール醴酵を維持することは非常に困難で，少な からず異常酸醅が関与する。その結果，酪酸など異常な 臭気と感しられる物質の副生が可能である。これに対し て, 低温の時期には, 漬贴床の安定した酸酻を維持しや

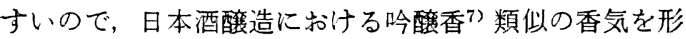
成させることが可能である。また，この香気の形成は， 皮膜形成菌の增殖と密接に関連しており, 皮膜形成後か ら強く感じられるようになる。

以上の結果から，同じ原料を使っても製造プロセス上 の違いが製品を大きく変えるとい党るし，古来からの伝 統的な食品は，それが伝光られた地域以外の者にとって は莻好品として利用されるにすぎない物であるといえ る。

\section{要約}

若狭の“サバなれずし”は，他地域で作られるものと は異なり，“へしこ”を原料とするもので，清酒モロミ 椂の芳香を有するものである。この“なれずし”製造過 程における各種成分の変化を調べて以下の結論を得た。
製品の香気の主成分はエチルアルコールと酶酸エチル であり, 漬け込み床液の表面に増殖する皮膜形成醅母の 增殖とともに增加するものである。

“なれずし”の熟成は, 漬け床の還元糖量が減少し, アミノ態窒素の增加, 有機酸量の增加によってもたらさ れるもので, 魚肉では遊離型アミノ酸, ペプチド型アミ ノ酸量の增加はもとより, 水溶性タンパク質画分の増加 によってなされるものである。

香気成分のガスクロマト分析のご指導，ご便宜を賜り ました京都大学農学部食品工学科農業分析学講座 小清 水弘一教授, 大東 肇助教授に心からの謝意を表しま す。

本報は第 41 回日本栄養食糧学会大会: 昭和 62 年 5 月 22 24 日（女子栄養大学）と昭和 63 年度日本農芸化学 会大会：昭和 63 年 4 月 $1 \sim 4$ 日（名城大学）で発表した ものである。

文献

1) 篠田 統：すしの本, 8 (1966), 柴田書店 (東京)

2) 刘谷泰弘, 木内律子: 福井大学教育学部紀要, 20 , 1 (1986)

3) 荻谷泰弘, 三上尚美: 福井大学教育学部紀要, 21, 1 (1987)

4) 芝田喜三代 : 酒造総典, 100 (1955), 高陽書店 (東京)

5）山口良夫, 山口辰良: 最新応用微生物 学入門, 262 (1966)，技報堂（東京）

6) 苅谷泰弘 : 未発表

7) 栗山一秀: 醱酵工学, 67, 105 (1989)

(1989 年 7 月 7 日受理) 